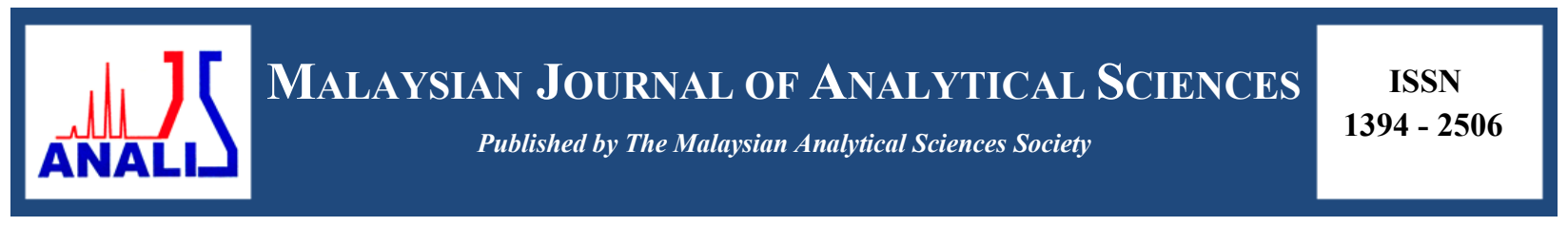

\title{
THE SYNTHESIS OF ZINC OXIDE/CARBON SPHERES NANOCOMPOSITES AND FIELD ELECTRON EMISSION PROPERTIES
}

\author{
(Sintesis Nanokomposit Zink Oksida/Sfera Karbon dan Sifat Pemancaran Elektron Medan) \\ Suriani Abu Bakar ${ }^{1,2 *}$, Suhufa Alfarisa ${ }^{1,2,3}$, Azmi Mohamed ${ }^{1,4}$, Norhayati Hashim ${ }^{1,4}$ \\ ${ }^{I}$ Nanotechnology Research Centre, Faculty of Science and Mathematics \\ ${ }^{2}$ Department of Physics, Faculty of Science and Mathematics \\ Universiti Pendidikan Sultan Idris, 35900 Tanjung Malim, Perak, Malaysia \\ ${ }^{3}$ Department of Physics, Faculty of Mathematics and Natural Science, \\ Universitas PGRI Palembang, Jl. Jend Ahmad Yani 9/10 Ulu, Palembang 30251, South Sumatera, Indonesia \\ ${ }^{4}$ Department of Chemistry, Faculty of Science and Mathematics, \\ Universiti Pendidikan Sultan Idris, 35900 Tanjung Malim, Perak, Malaysia \\ *Corresponding author: absuriani@yahoo.com
}

Received: 19 November 2016; Accepted: 6 March 2017

\begin{abstract}
Zinc oxide ( $\mathrm{ZnO})$ /carbon spheres (CS) nanocomposites were successfully synthesised using waste engine oil as precursor for the $\mathrm{CS}$ production. $\mathrm{ZnO}$ nanorods were grown using sol-gel immersion method with $\mathrm{MgZnO}$ as the seeded catalyst and thermal chemical vapour deposition was used to synthesise CS. Different configurations of $\mathrm{ZnO} / \mathrm{CS}$ structures were prepared i.e. CScoated $\mathrm{ZnO}$ and $\mathrm{ZnO}$-coated $\mathrm{CS}$. The structures of composite samples were analysed using field emission scanning electron microscopy (FESEM), Energy-Dispersive X-ray (EDX), micro-Raman and X-ray Diffraction Spectroscopy (XRD). FESEM observations revealed the structural changes of pristine $\mathrm{ZnO}$ and $\mathrm{CS}$ in composite structures. The as-present of $\mathrm{ZnO}$ or CS was believed to affect the subsequent growth of another structure. Field electron emission (FEE) properties of both nanocomposites

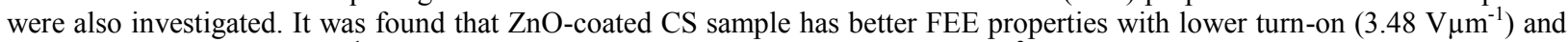

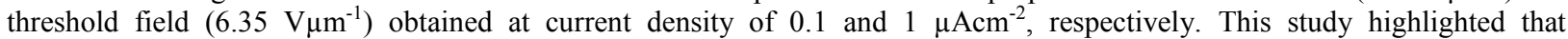
nanocomposites of $\mathrm{ZnO}$ and $\mathrm{CS}$ have successfully enhanced the field emission performances of materials compared with pristine $\mathrm{ZnO}$ or $\mathrm{CS}$ due to the structural changes of material emitter.
\end{abstract}

Keywords: zinc oxide, carbon spheres, waste engine oil, field electron emission

Abstrak

Nanokomposit zink oksida (ZnO)/sfera karbon (SK) telah berjaya disintesis menggunakan minyak enjin terpakai sebagai pelopor untuk penghasilan SK. Nanorod $\mathrm{ZnO}$ telah ditumbuhkan menggunakan kaedah rendaman sol-gel dengan $\mathrm{MgZnO}$ sebagai pemangkin berbenih dan pemendapan wap kimia terma telah digunakan untuk mensintesis SK. Konfigurasi yang berlainan bagi struktur $\mathrm{ZnO} / \mathrm{SK}$ telah disediakan iaitu $\mathrm{SK}$ bersalut $\mathrm{ZnO}$ dan $\mathrm{ZnO}$ bersalut $\mathrm{SK}$. Struktur sampel komposit dianalisis menggunakan Mikroskop Imbasan Elektron Pancaran Medan (FESEM), penyerakan tenaga sinar-X (EDX), spektroskopi mikroRaman dan pembelauan sinar-X (XRD). Pemerhatian FESEM menunjukkan perubahan struktur ZnO dan CS tulen dalam struktur komposit. $\mathrm{ZnO}$ atau CS sedia ada dipercayai memberi kesan kepada pertumbuhan seterusnya struktur lain. Sifat pemancaran elektron medan (PEM) bagi kedua-dua nanokomposit juga turut dikaji. Kajian mendapati bahawa sampel $\mathrm{ZnO}$

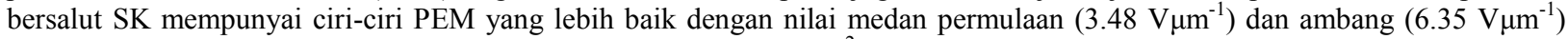
yang lebih rendah diperolehi pada ketumpatan arus 0.1 dan $1 \mu \mathrm{Acm}^{-2}$. Kajian ini menekankan nanokomposit ZnO dan SK telah berjaya meningkatkan prestasi pemancaran medan bahan berbanding dengan $\mathrm{ZnO}$ atau CS tulen disebabkan oleh perubahan struktur bahan pemancar. 


\section{Suriani et al: THE SYNTHESIS OF ZINC OXIDE/CARBON SPHERES NANOCOMPOSITES AND FIELD ELECTRON EMISSION PROPERTIES}

Kata kunci: zink oksida, sfera karbon, minyak enjin terpakai, pemancaran elektron medan

\section{Introduction}

Field emission is a quantum process of electron emission from a material where the electrons in Fermi level tunnel the energy barrier to vacuum level under high applied electric field [1]. Emission characteristics of a material are based on the Fowler-Nordheim (F-N) theory as followed in Eq. 1 [2]:

$$
J=\frac{A(\beta E)^{2}}{\varphi} \exp \left(\frac{B \varphi^{3 / 2}}{\beta E}\right)
$$

The current emission density $(\mathrm{J})$ at applied electric field $(\mathrm{E})$ can be calculated from the above equation. A and B are constants of $1.54 \times 10^{-6} \mathrm{AV}^{-2} \mathrm{eV}$ and $6.83 \times 10^{9} \mathrm{eV}^{-3 / 2} \mathrm{Vm}^{-1}$, respectively. Field enhancement factor of emitter $(\beta)$ is an important FEE characteristic and can be calculated from the slope of $\ln \left(\mathrm{J} / \mathrm{E}^{2}\right)$ vs $1 / \mathrm{E}$ curve using the equation $\beta=$ $-\mathrm{B} \varphi^{3 / 2} / \mathrm{slope}$. A typical benchmark that have been reported in the literature for FEE characterization comparison are the turn-on and threshold field, maximum current obtained (before the destruction of the emitter) as well as emission stability. Turn-on field for FEE is the field required to emit current density which is greater than the electrical noise-floor [3]. There is no agreement on the value of current density to be specified and the definition of turn-on and threshold field, it is determined by the group research themselves. For example, Ghosh et al. [4, 5] and Srivastava et al. [6] defined turn-on and threshold field to be the field required by the film to produce current density of $10 \mu \mathrm{Acm}^{-2}$ and $1 \mathrm{mAcm}^{-2}$ respectively. While Bonard and co-worker [90] specified the current density of $10 \mu \mathrm{Acm}^{-2}$ and $10 \mathrm{mAcm}^{-2}$ respectively. Since there is no specific definition of both turn-on and threshold field and as current density does not increase linearly with applied field, the result cannot be accurately compared. The comparisons between the results were only a rough estimation to claim that theirs is better than others. In this study, they are defined as the current density at applied field of 0.1 and $1 \mu \mathrm{Acm}^{-2}$, respectively for turn-on and threshold field.

To increase the FEE performance of the materials, it can be composited to further enhance the electron emission performance of those nanocomposites. Take carbon material such as carbon nanotubes (CNTs) as example, in view of its potential application as good electron emitters, however it can be easily degraded and damaged by the following factors [7-10], therefore the improvement of the FEE can be achieved by fabricating CNTs and zinc-oxide $(\mathrm{ZnO})$ as nanocomposites [11-13]. The order of the configuration of CNTs/ZnO composites is the crucial component that lead to the enhancement of field emission ability, where it frequently occurs that the materials fabricated at the top is more likely to help the FEE performances. $\mathrm{ZnO} / \mathrm{CNT}$ s nanocomposites structure have been reported to improve the FEE performance of material [1, 11-14]. In our recently published work [11], the investigation was done on the composite configuration to enhance the FEE performance by using two different configurations of $\mathrm{ZnO} /$ vertically aligned CNTs (VACNTs) where the order of the nanocomposites plays an important role in improving the FEE properties of pristine VACNTs.

The work revealed that the VACNTs-coated $\mathrm{ZnO}$ nanocomposites configuration showed a lower turn-on and

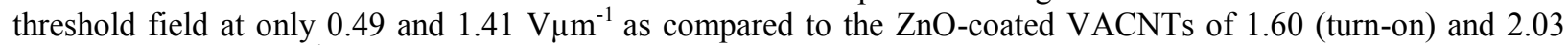

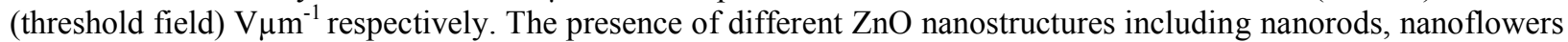
and nanorods-nanoflakes for ZnO-coated CNTs configuration were seen to play significant role towards enhancing FEE performances [13]. Among the $\mathrm{ZnO}$ nanostructured used the growth of CNTs on ZnO nanoflower demonstrated the highest FEE performance of $0.8 \mathrm{V \mu m}^{-1}$ at $1 \mathrm{uAcm}^{-2}$ of turn-on field. ZnO is a semiconducting material with wide direct band gap $(3.37 \mathrm{eV})$, large binding energy of $60 \mathrm{meV}$ and and work function of $5.3 \mathrm{eV}$ [1]. It has been applied in many electronic devices due to its unique and versatile properties [15-17]. ZnO nanostructures also showed promising application in field emission devices due to its high mechanical strength, chemical stability and good optical properties $[18,19]$. On the other hand, carbon materials are well known as a conducting material which is good for electron emission application. One type of carbon materials namely carbon spheres (CS) has been reported to have a comparable field emission properties as compared to other materials [20]. 
Here we presented the composite structures of $\mathrm{ZnO} / \mathrm{CS}$ and their FEE properties. To the best of our knowledge, this is the first report on the FEE of the CS synthesised from waste engine oil (WEO) with two different configurations of nanocomposite; CS-coated aligned $\mathrm{ZnO}$ nanorod and $\mathrm{ZnO}$ nanorod-coated CS sample. Recently, we reported the use of WEO for the production of another carbon material namely CNTs [21] and amorphous Al-Cu alloy nanowires decorated with CS [22]. The use of waste [23-27] and natural precursors [28-36] to produce carbon materials may not only be beneficial for nanotechnology research field but also preserve the environmental sustainability at the same time. The CS were synthesised using thermal chemical vapour deposition (TCVD) method while the $\mathrm{ZnO}$ were synthesised using the sol-gel method. The structural and field emission properties of $\mathrm{ZnO} / \mathrm{CS}$ nanocomposites samples were then systematically investigated.

\section{Materials and Methods}

The production of $\mathrm{ZnO} / \mathrm{CS}$ was performed in two different synthesis processes which were (i) the synthesis of $\mathrm{ZnO}$ nanorods using sol-gel immersion process and (ii) the synthesis of CS via thermal chemical vapour deposition (TCVD) method. Two different configurations were prepared as illustrated in Figure 1. For the CS-coated $\mathrm{ZnO}$ sample, $\mathrm{ZnO}$ nanorods were initially grown followed by the synthesis of $\mathrm{CS}$ and vice versa for the $\mathrm{ZnO}$-coated CS sample.
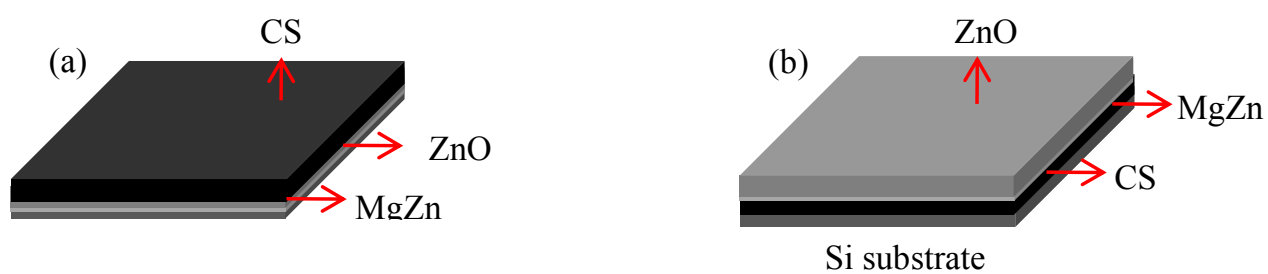

Figure 1. Different configurations of composite materials (a) CS-coated $\mathrm{ZnO}$ and (b) $\mathrm{ZnO}$-coated CS

The synthesis procedures of CS from WEO precursor was similar to previous report [21, 22]. However, different synthesis parameters were used. An amount $3 \mathrm{ml}$ of WEO mixed with $5.33 \mathrm{wt} \%$ ferrocene catalyst was heated at $450{ }^{\circ} \mathrm{C}$ in precursor zone and deposited onto Si substrate in $800{ }^{\circ} \mathrm{C}$ synthesis furnace. The synthesis process was carried out for $30 \mathrm{~min}$ under Ar gas flow at the rate of $0.25 \mathrm{Lmin}^{-1}$. Meanwhile, the synthesis of $\mathrm{ZnO}$ nanorods was adopted from [37]. MgZnO was initially deposited as the seeded catalyst. Collected samples were characterized using field emission scanning electron microscopy (FESEM-Hitachi SU8020), energy-dispersive X-ray (EDX), micro-Raman spectroscopy (Horiba Jobin Yvon-DU420A-OE-325) and X-ray diffraction (XRD) instrument (Bruker AXS D9). Field emission properties of the samples were measured using FEE equipment (Hewlett-Packard $34401 \mathrm{~A}$ multimeter) at emission area of $0.1 \mathrm{~cm}^{2}$ and distance between two electrodes was $100 \mu \mathrm{m}$.

\section{Results and Discussion}

Figure 2(a) - (f) present the FESEM images of the prepared $\mathrm{ZnO}$ nanorods, CS and their nanocomposites with different configurations. It was observed in Figure 2 (a) that the $\mathrm{ZnO}$ nanorods were vertically aligned with length up to $1.6 \mu \mathrm{m}$. Wide diameter distribution of the rods in the range of $42.8-285.7 \mathrm{~nm}$ were measured. This was due to the non-unifom $\mathrm{MgZnO}$ particles size as the template for the $\mathrm{ZnO}$ nanorods growth. The growth of $\mathrm{ZnO}$ nanorods was also believed occurred on the collection of agglomerated $\mathrm{MgZnO}$ particles. High density of CS was obtained with diameter of the spheres were ranged from 0.17 to $2.57 \mu \mathrm{m}$ as seen in Figure 2(b). The morphology of CS was modified after grown on $\mathrm{ZnO}$ nanorods as seen in Figure 2(c) and (d). Most of the spheres were decorated with short tube-like particles and grains which seemed to grow covering the CS. This was believed due to the adsorption of $\mathrm{ZnO}$ particles on the surface of CS which further become the catalyst for the secondary growth of short tube-like carbon structure. Somehow, the perfectly round shape of CS was still observed with diameter range from 1.1 to 2.7 $\mu \mathrm{m}$.

Figure 2(e) and (f) show the FESEM observation of ZnO-coated CS sample. High density and uniformly grown $\mathrm{ZnO}$ nanorods on $\mathrm{CS}$ were observed. Slightly different to the pristine aligned $\mathrm{ZnO}$ nanorods, flower-like $\mathrm{ZnO}$ 
nanostructures consisted of many hexagonal rods were also produced on the top of $\mathrm{ZnO}$ nanorods. The diameter of the rods was observed to be between 31.3 to $187.5 \mathrm{~nm}$, in the smaller range as compared to pristine $\mathrm{ZnO}$. This indicated the important presence of $\mathrm{CS}$ as the nucleation site for the growth of $\mathrm{ZnO}$ nanostructures. $\mathrm{MgZnO}$ particles were believed to be well deposited with uniform size on the CS, thus produced a better growth of $\mathrm{ZnO}$ nanostructures. Only small amount of CS was still observed as seen in the inset of Figure 2(f). The perfect alignment of $\mathrm{ZnO}$ nanorods cannot be observed due to the spherical shape of CS template. $\mathrm{ZnO}$ nanorods were initially grown on the uneven surface of $\mathrm{MgZnO}$-coated CS template. Once the saturated condition was achieved, nucleation of aligned $\mathrm{ZnO}$ nanorods got slower. There was no more space for the growth of nanorods on the $\mathrm{MgZnO}$-coated CS template, hence the $\mathrm{ZnO}$ particles started to nuclei on the top of the rods. Then, the aggregated $\mathrm{ZnO}$ particles formed the flower-like structure as can be observed in Figure 2(e)-(f).
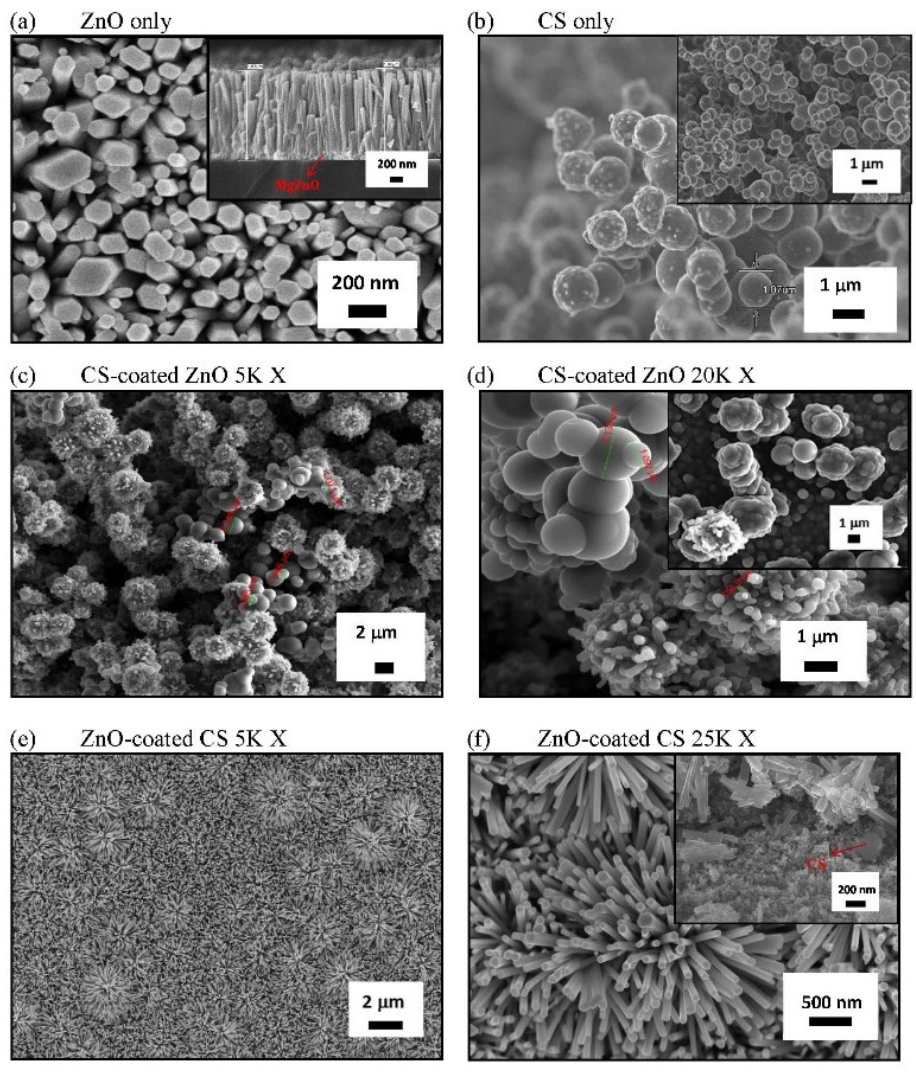

Figure 2. FESEM images of (a) $\mathrm{ZnO}$ nanorods, (b) $\mathrm{CS}$, (c-d) CS-coated $\mathrm{ZnO}$ and (e-f) $\mathrm{ZnO}$-coated CS nanocomposites

EDX analysis was performed to investigate the elemental compositions of the composite materials. Figure 3 show the EDX spectrum of both $\mathrm{ZnO}$-coated CS and CS-coated $\mathrm{ZnO}$ samples. Carbon, oxygen, and $\mathrm{Zn}$ elements were detected from overall structure. The Si peaks was believed to come from the substrate used. The average atomic of zinc and oxygen was found to be 1:1 which indicated a good stoichiometric ratio of $\mathrm{ZnO}$. Moreover, low amount of $\mathrm{Mg}$ element can be detected in this sample. The concentration of $\mathrm{Zn}$ atoms decreased in the CS-coated $\mathrm{ZnO}$ sample. This was in line with FESEM observation where during the synthesis of CS at high temperature of $800^{\circ} \mathrm{C}$, the $\mathrm{ZnO}$ nanorods were fully etched and turned to be $\mathrm{ZnO}$ flakes structure. In the meantime, $\mathrm{Zn}$ and oxygen atoms were also suspected to be adsorbed on the surface of CS. 

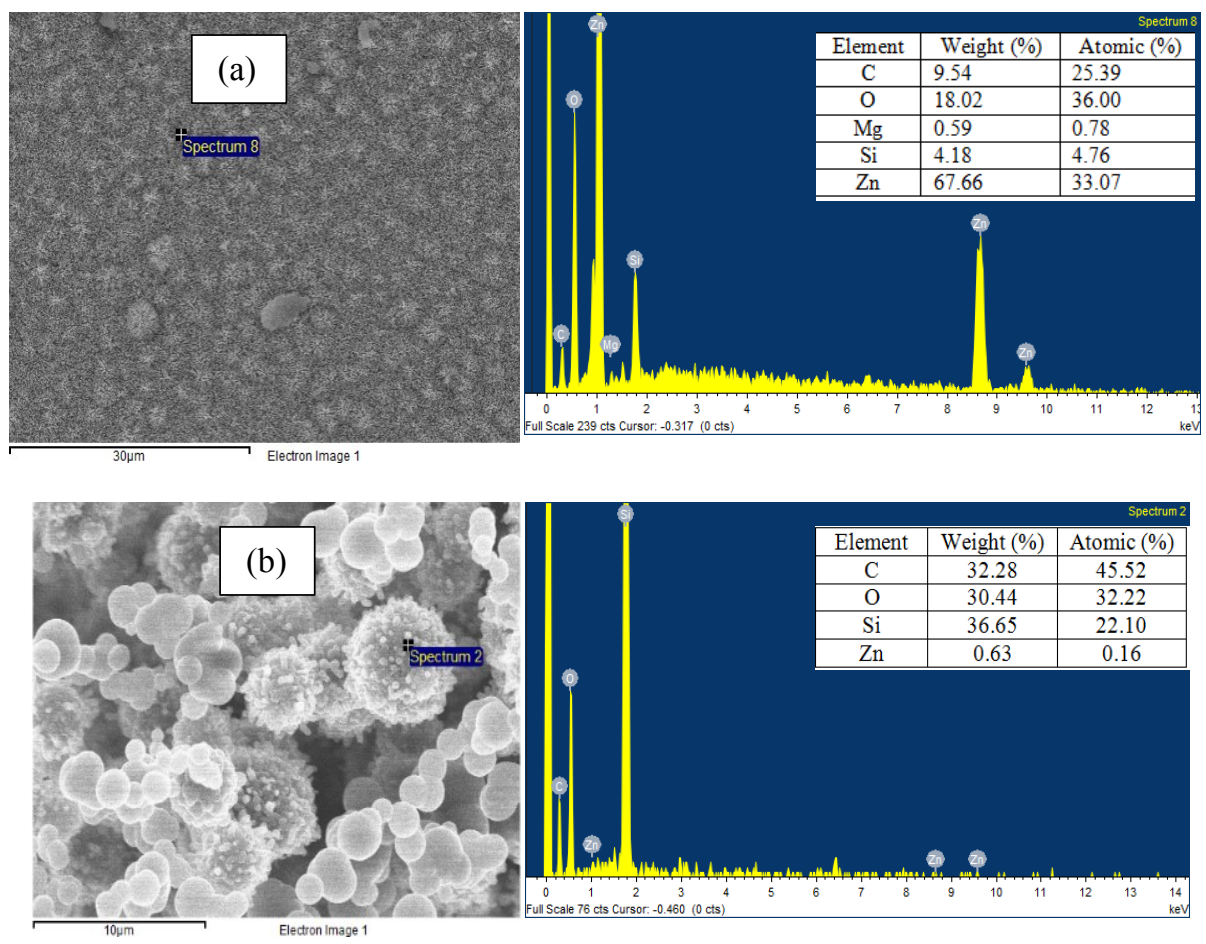

Figure 3. EDX analysis showing elemental compositions of $\mathrm{ZnO} / \mathrm{CS}$ nanocomposites (a) $\mathrm{ZnO}$-coated $\mathrm{CS}$ and (b) CS-coated $\mathrm{ZnO}$

Micro-Raman spectra of the as-prepared samples are presented in Figure 4. The micro-Raman spectrum of pristine CS shows the $D$ (disorder) and $G$ (graphitic) band at 1357.70 and $1598.2 \mathrm{~cm}^{-1}$, respectively with the intensity ratio of $D$ and $G$ band $\left(I_{D} / I_{G}\right)$ ratio was found to be 0.79 . Micro-Raman spectrum of $\mathrm{ZnO}$ nanorods only shows one typical $\mathrm{ZnO}$ characteristics at $438.18 \mathrm{~cm}^{-1}$ attributed to the $\mathrm{E}_{2}$ (high) modes. It also confirmed wurtzite hexagonal phase of $\mathrm{ZnO}$ nanorods. Peak at $303.76 \mathrm{~cm}^{-1}$ was derived from the use of $\mathrm{Si}$ as the substrate. Micro-Raman spectra of $\mathrm{ZnO} / \mathrm{CS}$ nanocomposites present both characteristic peaks of materials. $\mathrm{ZnO}$-coated CS remained show the wurtzite hexagonal phase of $\mathrm{ZnO}$ characteristic at $438.18 \mathrm{~cm}^{-1}$ which presented by a clear $\mathrm{E}_{2}$ (high) mode.

Only CS characteristics can be observed from the Raman spectrum of CS-coated $\mathrm{ZnO}$ sample. However, microRaman spectrum at lower shift range Figure 4(b) showed a sharp low intense peak at $444.13 \mathrm{~cm}^{-1}$ which corresponded to Raman active mode of wurtzite $\mathrm{ZnO}$ structure $\left(\mathrm{E}_{2}\right.$ high). This mode was shifted to a higher number. It might due to the increase of the stress or defect in the $\mathrm{ZnO}$ crystal [38]. Moreover, $I_{D} / I_{G}$ ratio of the CS increased to be 0.91 ( $\mathrm{ZnO}$-coated CS) and 0.88 (CS-coated $\mathrm{ZnO}$ ) after being composited with $\mathrm{ZnO}$. These indicated the lower crystallinity of CS in both composite structures as compared to the pristine CS. The reasonable explanation to these occurrences was due to the changes of CS structure after being combined with $\mathrm{ZnO}$. In case of $\mathrm{ZnO}$-coated CS sample, annealing process of $\mathrm{MgZnO}$ thin layer and $\mathrm{ZnO}$ nanorods alter the structure of $\mathrm{CS}$ where it introduced more defect of $\mathrm{C}-\mathrm{C}$ bonding in the spheres. The highest ratio of 0.91 was obtained from this structure. In addition, for the growth of $\mathrm{CS}$ on $\mathrm{ZnO}$ nanostructures, defect-induced from the bonding of carbon from $\mathrm{CS}$ and oxygen from the $\mathrm{ZnO}$ nanostructures was responsible to the higher defect of CS [13]. 

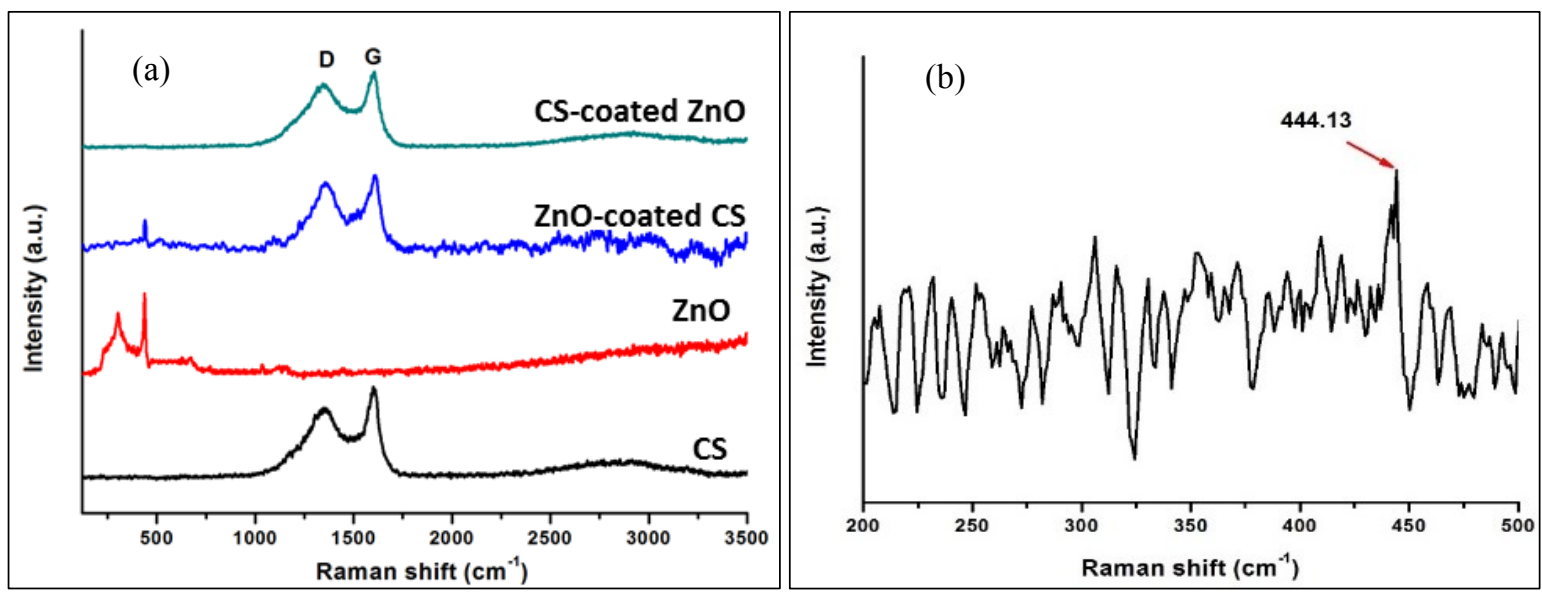

Figure 4. (a) Micro-Raman spectra of $\mathrm{ZnO} / \mathrm{CS}$ nanostructures and (b) Raman profile at lower wavenumber of CScoated $\mathrm{ZnO}$ structure shows the shift of $\mathrm{E}_{2}$ high mode due to the compressive stress

Typical XRD patterns of $\mathrm{ZnO} / \mathrm{CS}$ nanostructures are presented in Figure 5. Both samples show the characteristic peaks of $\mathrm{ZnO}$ and carbon. Similar to the pristine $\mathrm{ZnO}$ nanorods, the most intense peak was observed at $\sim 34^{\circ}$ along the (002) orientation [19]. ZnO-coated CS sample presents a broad and low intense peak at $43.40^{\circ}$ which attributed to carbon phase from CS. Another $\mathrm{ZnO}$ peak was shown by a low intense peak at $47.49^{\circ}$ along the (102) orientation. Diffraction peaks of $\mathrm{ZnO}$ in CS-coated $\mathrm{ZnO}$ sample are located at $2 \theta$ of $34.49,36.15,47.60$ and $56.20^{\circ}$ which are in good agreement with the standard of hexagonal ZnO crystal (PDF-01-080-0075). Meanwhile, carbon phase at 44.67 and $52.3^{\circ}$ are well matched with the standard of cubic carbon crystal (PDF-01-080-0017) with the lattice parameter of $3.539 \AA$.

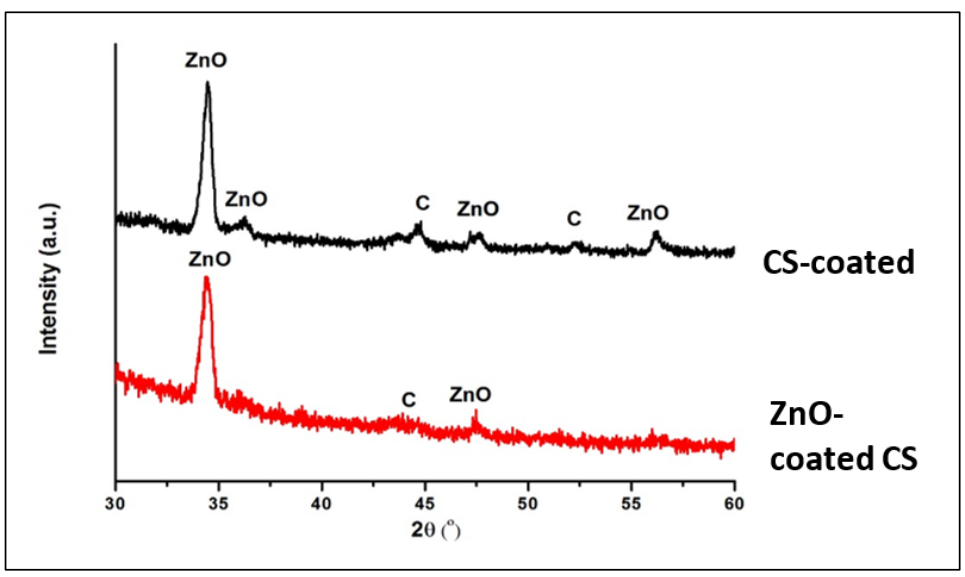

Figure 5. XRD patterns of $\mathrm{CS} / \mathrm{ZnO}$ nanostructures composites

Figures 6 and 7 present the J-E and F-N plot of different $\mathrm{ZnO}$ and $\mathrm{ZnO} / \mathrm{CS}$ nanocomposites materials. The measurements were taken at fixed electrodes separation of $100 \mu \mathrm{m}$ and applied voltage was increased from 0 to $1000 \mathrm{~V}$. Table 1 presents the summary of FEE characteristics of the as-prepared samples. Several repeated measurements have been conducted on the CS sample, but the current emission was still not observed. Due to its spherical structure, CS are less suitable to be applied as electron emitter. $\mathrm{ZnO}$ nanorods possessed moderate turn on 
and threshold fields at 5.65 and $7.34 \mathrm{~V} / \mu \mathrm{m}$, respectively with maximum current density of $3.46 \mu \mathrm{A} / \mathrm{cm}^{2}$. Composite structures of $\mathrm{ZnO} / \mathrm{CS}$ successfully enhanced the FEE properties. Turn on and threshold values of CS-coated $\mathrm{ZnO}$ sample were founded to be at 6.83 and $7.88 \mathrm{~V} / \mu \mathrm{m}$ and maximum current density of $2.51 \mu \mathrm{A} / \mathrm{cm}^{2}$. Modification of CS structure with the presence of short tube-like carbon structure which covered the CS was believed promoted a better emission site as compared to pristine $\mathrm{CS}$. Interestingly, $\mathrm{ZnO}$-coated $\mathrm{CS}$ structure where the $\mathrm{ZnO}$ nanostructures were grown on CS as the template exhibited an obvious decrement in the turn on value to be as low as $3.48 \mathrm{~V} / \mu \mathrm{m}$ and the threshold field was also decreased to be $6.35 \mathrm{~V} / \mu \mathrm{m}$. This structure presented a better FEE performance compared with the pristine $\mathrm{ZnO}$ nanorods as well as CS-coated $\mathrm{ZnO}$ composite structure. In addition, highest $\beta$ value up to 5485 and maximum current density of $3.78 \mu \mathrm{A} / \mathrm{cm}^{2}$ were obtained. Higher conductivity of CS compared to $\mathrm{ZnO}$ nanorods promoted a better electron transfer from the $\mathrm{CS}$ through $\mathrm{ZnO}$ nanorods structures to the vacuum level at high applied voltage. Moreover, the high aspect ratio of $\mathrm{ZnO}$ nanostructures with a good crystallinity and uniform rods diameter were also responsible for the high $\beta$ value of $\mathrm{ZnO}$-coated CS composite material [6].

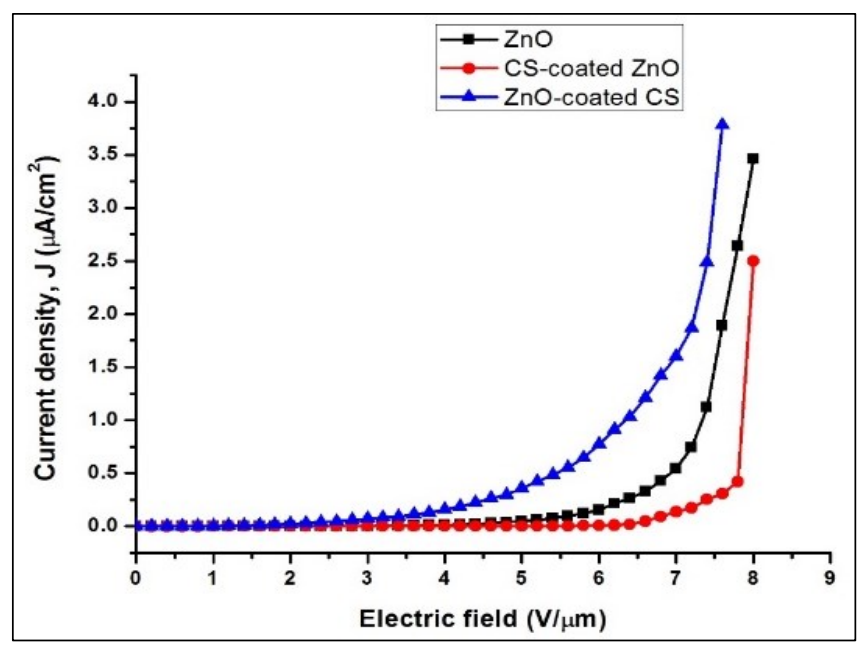

Figure 6. The J-E curves of the $\mathrm{ZnO}$ and $\mathrm{ZnO} / \mathrm{CS}$ nanocomposites materials

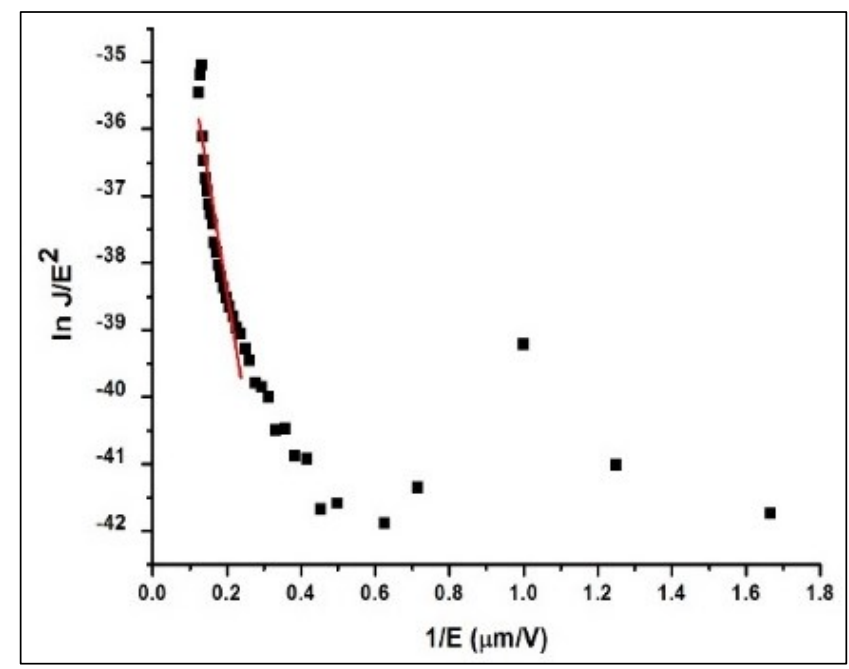

Figure 7. F-N plots of $\mathrm{ZnO}$ and $\mathrm{ZnO} / \mathrm{CS}$ nanocomposites materials (a) $\mathrm{ZnO}$, (b) CS-coated $\mathrm{ZnO}$ and (c) $\mathrm{ZnO}$ coated CS 
Table 1. FEE characteristics of CS, $\mathrm{ZnO}$ nanorods and their composite materials

\begin{tabular}{|c|c|c|c|c|}
\hline Sample & $\begin{array}{l}\text { Turn on Field at } \\
0.1 \mu \mathrm{A}(\mathrm{V} / \mu \mathrm{m})\end{array}$ & $\begin{array}{l}\text { Threshold Field } \\
\text { at } 1 \mu \mathrm{A}(\mathrm{V} / \mu \mathrm{m})\end{array}$ & $\begin{array}{c}J \operatorname{Max} \\
\left(\mu \mathrm{A} / \mathbf{c m}^{2}\right)\end{array}$ & $\beta$ \\
\hline $\mathrm{ZnO}$ & 5.65 & 7.34 & 3.46 & 2452 \\
\hline ZnO-coated CS & 3.48 & 6.35 & 3.78 & 5879 \\
\hline CS-coated $\mathrm{ZnO}$ & 6.83 & 7.88 & 2.51 & 755 \\
\hline
\end{tabular}

To study the emission current stability, a constant electric field was applied to the $\mathrm{ZnO}$ nanorods and $\mathrm{ZnO} / \mathrm{CS}$ nanocomposites materials for one hour duration time. The current vs time graphs for both samples are presented in Figure 8 and the detail of their current emission fluctuation order is given in Table 2. The current emission of $\mathrm{ZnO}$ nanorods was moderately stable since frequent fluctuations to a high current value were observed. This was due to the wide diameter range of $\mathrm{ZnO}$ nanorods. Smaller diameter rods proportional with the length and rods spacing is preferable for a better FEE performance. Although $\mathrm{ZnO}$ nanorods current emission was less stable, the emission of $\mathrm{ZnO}$ nanorods was found to be higher in the order of $10^{-6} \mathrm{~A}$ than the CNTs which was in the order of $10^{-7} \mathrm{~A}$ [11]. $\mathrm{ZnO}$ nanomaterials have negative electron affinity [18] which can support the current emission due to their ability to emit electrons to the vacuum with little energy loss.
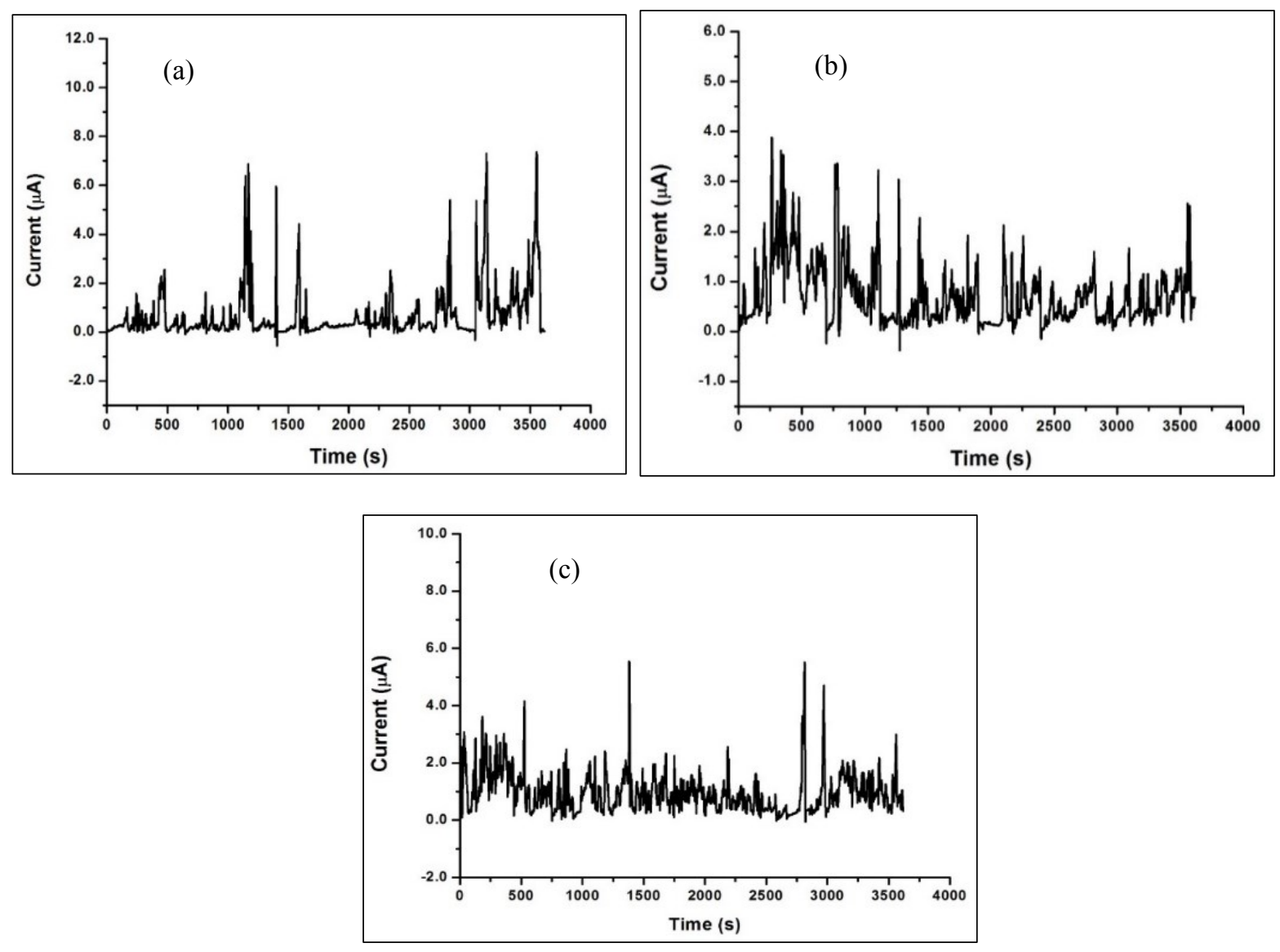

Figure 8. Current stability measurement of (a) $\mathrm{ZnO}$ and (b)-(c) $\mathrm{ZnO} / \mathrm{CS}$ nanostructures composites 
Table 2. Current emission fluctuation order of carbon material, $\mathrm{ZnO}$ nanorods and their composite structures

\begin{tabular}{lc}
\hline Sample & $\begin{array}{c}\text { Current Fluctuation Order } \\
\text { (Ampere) }\end{array}$ \\
\hline $\mathrm{ZnO}$ & $10^{-8}-10^{-6}$ \\
$\mathrm{ZnO}$-coated CS & $10^{-9}-10^{-6}$ \\
$\mathrm{CS}$-coated $\mathrm{ZnO}$ & $10^{-7}-10^{-6}$ \\
\hline
\end{tabular}

The growth of $\mathrm{ZnO}$ nanorods on CS sample gave better emission stability as compared to pristine $\mathrm{ZnO}$ and CScoated $\mathrm{ZnO}$ samples. This was believed due to the presence of as-grown CS and high uniformity with smaller $\mathrm{ZnO}$ nanorods, flower-like $\mathrm{ZnO}$ nanostructures size which is more favourable for electron emission application. High conductivity of carbon materials promoted better electrons transfer and led to the enhancement of field emission. Moreover, the carbon materials acted as the additional catalyst which improved the uniformity and crystal quality of $\mathrm{ZnO}$ nanostructures.

\section{Conclusion}

$\mathrm{ZnO} / \mathrm{CS}$ nanocomposites were successfully synthesised using the combination of sol-gel immersion and TCVD method. Waste material precursor namely WEO was used to produce CS in this study. The structure of $\mathrm{ZnO}$ and CS were modified after being composited. In case of CS-coated $\mathrm{ZnO}$, the structural change of CS was believed due to the adsorption of $\mathrm{ZnO}$ particles on the surface of CS. Meanwhile, the as-presence of CS in ZnO-coated CS sample has promoted a better growth $\mathrm{ZnO}$ nanostructure. This structure also presented the best FEE performances with the lowest turn on $(3.48 \mathrm{~V} / \mu \mathrm{m})$ and threshold field $(6.35 \mathrm{~V} / \mu \mathrm{m})$ as well as highest maximum current density (3.78 $\mu \mathrm{A} / \mathrm{cm}^{2}$ ) and field enhancement factor up to 5879 with better emission current stability. The presence of conductive carbon material which is CS promoted the well electron transfer from the CS through the $\mathrm{ZnO}$ nanostructures to vacuum level at high electric field. A better structure of $\mathrm{ZnO}$ nanorods with uniform diameter size was also responsible to the better FEE properties of this nanocomposites structure. It can be concluded that the $\mathrm{ZnO}$-coated CS nanocomposites has great future applications in field emission devices such as flat panel displays and flat lamps.

\section{Acknowledgement}

The authors are thankful to Fundamental Research Grant Scheme (Grant code: 2015-0154-102-02) and UPSI for financial and technical supports of this work.

\section{References}

1. Patra, R., Ghosh, S., Sharma, H. and Vankar V. D. (2013). High stability field emission from zinc oxide coated multiwalled carbon nanotube films. Advanced Materials Letters, 4 (11): 849 - 855.

2. Fowler, R. H. and Nordheim, L. (1928). Electron emission in intense electric fields. Proceedings of the Royal Society of London. Series A, 119 (781): 173 - 18.

3. Leong, J. G. S. (2008). Controlled growth of uniform diameter multiwall carbon nanotube arrays via chemical vapor deposition for application in field emission devices. Master Thesis Northeastern University, Boston, Massachusetts, USA.

4. Ghosh, P., Subramanian, M., Afre, R. A., Zamri, M., Soga, T., Jimbo, T., Filip, V. and Tanemura, M. (2009). Growth of Y-junction bamboo-shaped $\mathrm{CNx}$ Nanotubes on GaAs substrate using single feedstock. Applied Surface Science, 255(8): $4611-4615$.

5. Ghosh, P., Zamri, M., Subramanian, M., Soga, T., Jimbo, T., Katoh, R. and Tanemura, M. (2008). Bambooshaped aligned CNx nanotubes synthesized using single feedstock at different temperature and study of their field electron emission. Journal of Physics D: Applied Physics, 41 (15): 155405 - 155412.

6. Srivastava, S. K., Vankar, V. D., Sridhar Rao, D. V. and Kumar, V. (2006). Enhanced field emission characteristics of nitrogen-doped carbon nanotube films grown by microwave plasma enhanced chemical vapor deposition process. Thin Solid Films, 515: 1851 - 1856. 
7. Hu, H., Zhang, D., Liu, Y., Yu, W. and Guo, T. (2015). Highly enhanced field emission from CuO nanowire arrays by coating of carbon nanotube network films. Vacuum, 115: $70-74$.

8. Yan, X., Tay, B. K. and Miele, P. (2008). Field emission from ordered carbon nanotube-ZnO heterojunction arrays. Carbon, 46: $753-758$.

9. Cai, D. and Liu, L. (2013). The screening effects of carbon nanotube arrays and its field emission optimum density. AIP Advances, 3 (12): 122103.

10. Heo, Y. W., Tien, L. C., Kwon, Y., Norton, D. P., Pearton, S. J., Kang, B. S. and Ren, F. (2004). Depletionmode $\mathrm{ZnO}$ nanowire field-effect transistor. Applied Physics Letters, 85 (12): 2274 - 2276.

11. Suriani, A. B., Dalila, A. R., Mohamed, A., Mamat, M. H., Malek, M. F., Soga, T. and Tanemura, M. (2016). Fabrication of vertically aligned carbon nanotubes-zinc oxide nanocomposites and their field electron emission enhancement. Materials Design, 90: 185 - 195.

12. Suriani, A. B., Safitri, R. N., Mohamed, A., Alfarisa, S., Isa, I. M., Kamari, A., Hashim, N., Ahmad, M. K., Malek, M. F. and Rusop M. (2015). Enhanced field electron emission of flower-like zinc oxide on zinc oxide nanorods grown on carbon nanotubes. Materials Letters, 149: 66 - 69.

13. Suriani, A. B., Safitri, R. N., Mohamed, A., Alfarisa, S., Malek, M. F., Mamat, M. H. and Ahmad M. K. (2016). Synthesis and field electron emission properties of waste cooking palm oil-based carbon nanotubes coated on different zinc oxide nanostructures. Journal of Alloys and Compounds, 656: 368 -377.

14. Dutta, M. and Basak, D. (2019). Multiwalled carbon nanotubes/ZnO nanowires composite structure with enhanced ultraviolet emission and faster ultraviolet response. Chemical Physics Letters, 480(4-6): 253 -257.

15. Flickyngerová, S., Tvarožek, V. and Gašpierik, P. (2010). Zinc oxide - A unique material for advanced photovoltaic solar cells. Journal of Electrical Engineering, 61(5): 291 - 295.

16. Nohavica, D. and Gladkov. P. (2010). ZnO nanoparticles and their applications-new achievements. Proceedings of the $2^{\text {nd }}$ International Conference on Nanotechnology, 10: $12-14$.

17. Vaseem, M., Umar, A. and Hahn, Y. B. (2010). ZnO nanoparticles: Growth, properties, and applications. American Scientific Publishers, New York: pp. 1-36.

18. Jin, H., Li, Y., Li, J. and Gu, C. (2009). Field emission from $\mathrm{ZnO}$ nanostructures with different morphologies. Microelectronic Engineering, 86 (4): 1159 - 1161.

19. Mamat, M. H., Khusaimi, Z., Zahidi, M. M., Suriani, A. B., Siran, Y. M., Rejab, S. A. M., Asis, A. J., Tahiruddin, S., Abdullah, S. and Rusop M. (2011). Controllable growth of vertically aligned aluminum-doped zinc oxide nanorod arrays by sonicated sol-gel immersion method depending on precursor solution. Japanese Journal of Applied Physics, 50: 1 - 6.

20. Banerjee, D., Sen, D. and Chattopadhyay, K. K. (2013). Simple chemical synthesis of porous carbon spheres and its improved field emission by water vapor adsorption. Microporous and Mesoporous Materials, 171: 201 $-207$.

21. Suriani, A. B., Alfarisa, S., Mohamed, A., Isa, I. M., Kamari. A., Hashim, N., Mamat, M. H., Mohamed, A. R. and M. Rusop, M. (2015). Quasi-aligned carbon nanotubes synthesised from waste engine oil. Materials Letters, 139: $220-223$.

22. Suriani, A. B., Alfarisa, S., Mohamed, A., Kamari. A., Hashim, N., Isa, I. M., Mamat, M. H., Malek, M. F. and Ahmad, M. K. (2015). Amorphous Al-Cu alloy nanowires decorated with carbon spheres synthesised from waste engine oil. Journal of Alloys and Compounds, 642: 111 - 116.

23. Suriani, A. B., Nor, R. M. and Rusop, M. (2010). Vertically aligned carbon nanotubes synthesized from waste cooking palm oil. Journal Ceramic Society Japan, 118: 963 - 968.

24. Suriani, A. B., Dalila, A. R., Mohamed, A., Mamat, M. H., Salina, M., Rosmi M. S., Rosly, J., Nor, R. M. and Rusop, M. (2013), Vertically aligned carbon nanotubes synthesized from waste chicken fat. Materials Letters, 101: $61-64$.

25. Suriani, A. B., Dalila, A. R., Mohamed, A., Isa, I. M., Kamari, A., Hashim, N., Soga, T. and Tanemura, M. (2015). Synthesis of carbon nanofibres from waste chicken fat for field electron emission applications. Materials Research Bulletin, 70: 524 - 529.

26. Suriani, A. B., Norhafizah, J., Mohammed, A., Mamat, M. H., Malek, M. F. and Ahmad, M. K. (2016). Scaledup prototype of carbon nanotube production system utilizing waste cooking palm oil precursor and its nanocomposite application as supercapacitor electrodes. Journal of Materials Science: Materials in Electronics, 27(11): 11599 - 11605 . 
27. Suriani, A. B., Dalila, A. R., Mohamed, A., Soga, T. and Tanemura, M. (2015). Synthesis, structural, and field electron emission properties of quasi-aligned carbon nanotubes from gutter oil. Materials Chemistry and Physics, 165: $1-7$.

28. Azmina, M. S., Suriani, A. B., Falina, A. N., Salina, M. and Rusop, M. (2012). Temperature effects on the production of carbon nanotubes from palm oil by thermal chemical vapor deposition method. Advanced Materials Research, 364: 359 - 362.

29. Azmina, M. S., Suriani, A. B., Falina, A. N., Salina, M., Rosly, J. and Rusop, M. (2012). Preparation of palm oil based carbon nanotubes at various ferrocene concentration. Advanced Materials Research, 364: 408 - 441.

30. Shamsudin, M. S., Suriani, A. B., Abdullah, S., Yahya, S. Y. S. and Rusop, M. (2013). Impact of thermal annealing under nitrogen ambient on structural, micro-raman, and thermogravimetric analyses of camphoricCNT. Journal of Spectroscopy, 2013: 1 - 7.

31. Azmina, M. S., Suriani, A. B., Salina, M., Azira, A. A., Dalila, A. R., Asli, N. A., Rosly, J., Nor, R. M. and Rusop, M. (2012). Variety of bio-hydrocarbon precursors for the synthesis of carbon nanotubes. Nano Hybrids, 2: $43-63$.

32. Zobir, S. A. M., Bakar, S. A., Abdullah, S., Zainal, Z., Sarijo, S. H. and Rusop, M. (2012). Raman spectroscopic study of carbon nanotubes prepared using $\mathrm{Fe} / \mathrm{ZnO}$-palm olein-chemical vapour deposition. Journal of Nanomaterials, 2012: $1-6$.

33. Asli, N. A., Shamsudin, M. S., Suriani, A. B., Rusop, M. and Abdullah, S. (2013). Effect of the ratio of catalyst to carbon source on the growth of vertically aligned carbon nanotubes on nanostructured porous silicon templates. International Journal of Industrial Chemistry, 4(23): 1 - 7.

34. Asli, N. A., Shamsudin, M. S., Falina, A. N., Azmina, M. S., Suriani, A. B., Rusop, M. and Abdullah, S. (2013). Field electron emission properties of vertically aligned carbon nanotubes deposited on a nanostructured porous silicon template: the hidden role of the hydrocarbon/catalyst ratio. Microelectronic Engineering, 108: 86 $-92$.

35. Suriani, A. B., Azira, A. A., Nik, S. F., Nor R. M. and Rusop, M. (2009). Synthesis of vertically aligned carbon nanotubes using natural palm oil as carbon precursor. Materials Letters, 63(30): $2704-2706$.

36. Shamsudin, M. S., Achoi, M. F., Asiah, M. N., Ismail, L. N., Suriani, A. B., Abdullah, S., Yahya, S. Y. S. and Rusop, M. (2012). Synthesis and nucleation-growth mechanism of almost catalyst-free carbon nanotubes grown from Fe-filled sphere-like graphene-shell surface. Journal of Nanostructure in Chemistry, 3(13): 1 - 12.

37. Salina, M., Ahmad, R., Suriani, A. B. and Rusop, M. (2012). Bandgap alteration of transparent zinc oxide thin film with Mg dopant. Transactions on Electrical and Electronic Materials, 13(2): 64 - 68.

38. Wu, X., Wei, Z., Zhang, L., Wang, X., Yang, H. and Jiang, J. (2014). Optical and magnetic properties of Fe doped $\mathrm{ZnO}$ nanoparticles obtained by hydrothermal synthesis. Journal of Nanomaterials, 2014: 1 - 6. 